\title{
Art, Music and Religious Experience in Li- bation Pouring of Akan Religion
}

The Akans of Ghana are traditionally accustomed to celebrating different rituals which are enshrined in their cultural life. Libation pouring, which accompanies the celebration of great rituals, amidst the subsidence of the sound of music and dance, can display a special art in religion.

The primary objective of this paper is to examine libation as a ritual experience, and in so doing to draw attention to its art forms and relevance as regards the psychological significance for the Akan society which practises it. At issue are the following kinds of questions. What do we mean by the term "libation pouring"? What beliefs connect the pouring of libation in Akan society? What are the occasions for practising this ritual? Are there some distinctions in the artistic prayer of libation? These questions lead directly to the proposition which states that libation is able to generate some forms of religious experience. It is then argued that libation ritual has psychological consequences beneficial to the group and the individual who privately engages in it.

\section{What is Libation Pouring?}

Libation pouring is the activity whereby water, alcohol or any beverage, such as wine, is poured on the ground with the intention of invoking the spirits and requesting their assistance (Ayim-Aboagye 1993: 165). According to Platvoet, it is a verbal mode of address to one or more "metaempirical beings" and has the purpose of initiating or maintaining contact with them (Platvoet 1982: 201). Libation pouring signifies an apparent recognition by those who engage in it that they are under the control and direction of forces far more "powerful" and "wiser" than themselves. This activity is an acknowledgement by those who practise it that their collective and individual destinies do not lie in their own hands. The responsi- 
bilities are borne by God and the spirits of ancestors (Owusu-Mensa 1990: 3).

Libation is one of the commonest practices in Akan worship of the Supreme Being and the lesser beings or spirits. When any libation is poured, the personal name of the Supreme Being, Kwame, is mentioned first and He is asked to come and drink. The next to be called is the earth, personified as Thursday Earth (Asaase Yaa). After these two come the other Akan deities, ancestral spirits, etc. The drink which is poured on the ground is meant to "cool down the throats" of these deities and prepare them for a much more relaxed posture for hearing the petitions of human beings. Libation pouring has the function of welcoming God and the other spirits home into the human world (Owusu-Mensa 1990: 30).

An example of libation pouring is quoted by Opoku which portrays a priest inviting the Supreme Being, gods and spirits to wash their hands in preparation for a feast. According to Opoku, the priest recites the following words:

Oh Tweaduampon Kwame,

Toturobonsu, the rain-maker,

Ammaowia-the giver of sunshine,

Receive drink,

Yaa, the Earth goddess,

Receive drink;

Nana Ntoa, receive drink;

Kyenku god, here is drink for you.

When I call one of you

I have called all.

Ye departed spirits of the seven

Akan clans,

Receive drink.

Today is your lustral day.

I have brought you a sheep, drink

and new yam.

Receive these and visit us

This new year with a good harvest,

Wealth and prosperity, fertility and

long life,

Peace and fame and rain and sunshine

At their appropriate times.

If ever we are called upon

To share three things with any other

nation, 
Let us have two.

Let the evil one that plans evil for us

Receive evil in return (Opoku 1970: 1-31).

\section{The Prevalence of Libation Pouring}

The pouring of libation expresses the sense of dependence on spiritual beings. According to $\mathrm{Akan}^{1}$ beliefs, the universe is filled with different spiritual beings. There is a Great Spirit, the Supreme Being, who created all things, and who reveals his power through his deputies called abosom (Busia 1954: 191). Nyame, the Great Being, is seen as the most important one and $\mathrm{He}$ is the one who sustains all. His many honorific titles characterize Him as closely associated with the visible sky and its phenomena, especially the rain. Even though he has withdrawn to the distant sky, He may be approached in prayer by man (Platvoet 1982: 41). The gods who can be approached directly, derive their power from the Supreme Being. They originate from the latter and are parts of him. A god is but the mouthpiece of the Supreme Being, a servant acting as intermediary between Creator and creature. Among these deities, the most powerful are the river-gods (Platvoet 1982: 41).

The Akan also worship the nsamanfo, the spirits of the departed ones. They are the ever-present spirits of the ancestors whose constant contact with the life of man on the earth brings the world of the spirits so close to the land of the living. The ancestors rule, protect and, if need be, punish the living (Busia 1954: 201). They are supposed to visit the living sometimes; they are said to be custodians and makers of tribal laws. They are also said to send help to their relatives (Sarpong 1974: 38). The argument here is that when the Christians call their dead saints and refer to those of pagans as ancestors, they are not expressing different ideas. They are essentially the same (Sarpong 1974: 33).

\footnotetext{
${ }^{1}$ To some extent libation pouring is common to some other ethnic communities of Ghana too (e.g. among the Gas and the Ewes).
} 


\section{Libation is Embedded in the Traditional mythology}

\section{The okyeame in the Akan mythology}

With the belief in these spiritual beings, it is not surprising that the Akan constantly tries to maintain contact with them. The libation activity is enshrined in the Akan mythology and is associated with the work of the okyeame. The okyeame (spokesman) is the individual who is traditionally selected to mediate between the Chief and his subjects or between a healer and his patients. In Akan culture, the chief or the healer is seen as eminent and therefore cannot be directly spoken to. The myth of okyeame is something that is widely cherished by people in that he performs a special function that puts him or her in the limelight. The qualifications of okyeame are that he needs to be intelligent in the eyes of the people. He should be able to recite a number of Akan proverbs from memory. The okyeame needs to be someone who is very eloquent and at times has to come from a royal home. He travels with the chief or the healer on all occasions and he is supposed to be present when the chief presides over a case in the Ahemfie (the Chief's palace). The okyeame may act as the chief's or healer's advisor in times of difficulty. He is the dominant person supposed to pour down libation to invoke the spirits, lesser spirits, the ancestral spirits and requests for their assistance. ${ }^{2}$ When the okyeame is absent, the choice of another person to perform this function becomes necessary. Usually a special staff of the okyeame which symbolizes his power and office is given to the individual before he can commence the pouring of libation.

\section{Occasions for the Pouring of Libation}

The pouring of libation is frequently practised during certain well known occasions.

At the Adae ceremonies the departed rulers are invoked, food and drink are offered to them and their favours are solicited for the welfare of the people. An Adae occurs every twenty-one days, known alternately as Kwasidae, or Adae kese, and Wukudae. The former, the Great Adae, falls

\footnotetext{
${ }^{2}$ Occasionally a chief or an elder with an outstanding respect can also pour libation, especially when it concerns libation in the stool-room (nkonguafie). Even on this special occasion it is the okyeame who becomes the major figure nodding in response while the group listens to the prayer.
} 
on Sundays, and the latter on Wednesdays, so that there are six weeks between one little Adae (Wukudae) and the next little Adae. Hence every third week, on an Adae day, whether it is a Great Adae or a little one, an Akan chief, especially an Ashanti chief, officiates before the ancestral stools and prays to his ancestors on behalf of the tribe, asking that the earth may be fruitful, and that the tribe may prosper and increase in numbers (Busia 1954: 203; Opoku 1970:7). On the eve of an Adae the talking drums announce to the people that the Adae falls on the following day. ${ }^{3}$ The stool treasurer and the stool carriers will already have secured the sheep and drink that will be needed. Early in the morning the chief, accompanied by his akyeame and elders, enters the stool-house (nkonguafie). As they enter the sacred place, they take their sandals off their feet and bare their shoulders as a mark of respect to the ancestors who are believed to be present where their stools are kept. The chief then reverently pours libation and offers drink and meat from a sheep that is slaughtered there to the ancestors. Placing a piece of meat on each stool, he pours libation with this prayer: "Today is Adae; come and receive this and eat; let the tribe prosper; let those of child-bearing age bear children; may all the people get money, long life to us all; long life to the tribe [ethnic group]" (Busia 1954: 203). Then he takes a bottle of rum, pours some into a glass and lets a few drops fall on each stool as he repeats the same prayer. When the rites in the stool-house are over, a public ceremony is held. The chief takes his seat in an open space or court-yard, surrounded by his councilors, drummers and minstrels. Each lineage head or sub-chief, accompanied by his subjects and members of his lineage, ceremonially greets the chief and takes his place in the gathering. There is drumming and dancing in which everyone is free to join. The minstrels chant the tradition of the tribe, and the brave deeds of its departed rulers (Busia 1954: 203).

The Odwira ceremony is an annual festival which can last from a week to a fortnight. Sheep, drink and the first harvest of the year are offered to the gods. As part of the celebrations, the chief and his people in a long procession visit the royal mausoleum (ban $m u$ ) and offer sacrifices and prayers. It is also a time of cleansing the tribe from defilement, and for purification of the shrines of the ancestral spirits and tribal gods. The rites of cleansing and purification usually take place in a stream where the chief takes a ritual bath, and water is sprinkled on the shrines and all who are present, as a symbolic act of cleansing. A particular sacrifice of a black hen

\footnotetext{
${ }^{3}$ This refers to the beating of drums to convey messages.
} 
symbolizes the removal of all that had defiled the tribe. At one Odwira ceremony libation was poured with a recital of these words:

Here is food; all you ancestors receive this and eat; the year has come around again; today we celebrate it; bring us blessing to the chief who sits on your stool; health to the people; let women bear children; let the men prosper in their undertakings; life to all; we thank you for the good harvest; for standing behind us well [i.e., guarding and protecting us]; Blessing, blessing, blessing (Busia 1954: 203).

Apart from these two occasions, regular meetings of chiefs and their elders in palaces are times when libation can also be poured to the Supreme Being, the gods and the ancestors. For instance, when an immediate answer or solution to a problem is needed, the okyeame summons the ancestors and the gods through libation. These circumstances can be any of these: illness; death of a person in a mysterious way; a missing person or a drowning in a river (Ayim-Aboagye 1993: 165). The summons of these spirits for assistance indicates the tribe's dependence on them, and they are treated with respect since the Akan believe they deliver assistance.

Healing settings are also places where libations are frequently poured to invoke the power and assistance of the Supreme Being, the gods and the ancestors. In fact nowhere are the powers of these beings needed more than the healing settings. At the healing setting, there is a healer who is the head of the cult and who is frequently possessed by the god (obosom) during gatherings. The healer has his okyeame, the spokesman, who mediates between the healer and his patients. The okyeame is, moreover, helped by many assistants, who are also members of the cult.

Funeral celebrations form an important aspect of the social life of the Akan. A funeral is an important social event carrying with it certain expectations in the behaviour of individuals. Its demand is often not solemnity or a quiet atmosphere, but rather the turbulence of a festival shorn of its glaring gaiety. Noises of drums and other musical instruments, the sound of guns and human voices singing, wailing or speaking intermingle on the situation of the funeral as related social expressions from individuals and groups of individuals (Akrofi 1955: 1).

Libation is poured at funeral ceremonies because the death of an individual means that he has to make a journey to the ancestors. On such occasions messages are sent to the ancestors who have already departed that they will soon be joined by one of the members of the family (abusua). Funeral celebrations in general therefore spring from the Akan conception of the Universe, and in particular from a belief in life after death. Funeral dirges are commonly sung during funeral ceremonies. Dirges deal with 
traditional expressions stored in the minds of individuals and re-created by them in appropriate contexts. They are sung in musical form correlating with sobs, gestures or other bodily movements (Akrofi 1955: 3). One prayer (Kankye) in a funeral ceremony goes like this:

Nana, X Y, man has no power to deny death of its prey

If your life could have been redeemed with persons or with money

Your relations and your people would have hesitated in

saving your life

But this has not been so as God also delights in man's own desires

You go to join the company of the elders [that is of the dead]

We pray that you have a good account to give them and block the path of death

Endeavour to save the few of us left behind from dying

Your people plan a grand funeral to honour you

We beseech you to help avoid any unpleasant occurrences at the funeral

A bad name is unpleasant

Whatever debts we incur let us find money to settle

(Kyerematen s. a.: 7-9).

\section{Some Analytical Distinctions of Libation's Prayer}

I consider it appropriate to examine some analytical distinctions proposed within the framework of prayer. Prayer is simultaneously said during the ritual of libation pouring. Prayer is a "communication between believers and the meta-empirical beings [spirits]" (Platvoet 1982: 9).

There are three pairs of analytical distinctions of prayer. The first is that between "single" and "serial" prayers. The second type is between "introductory" and "supplementary" prayers. The third is that between "complete" and "incomplete", or "partial" prayer (Platvoet 1982: 9). A single prayer is "a unit of address in which only one message is sent." The message may be addressed to one "meta-empirical being", or to more such beings in their collectivity, or to a number of distinct meta-empirical beings who are summoned "serially", that is one after another, but to whom but one and the same message is directed (Platvoet 1982: 9). A serial prayer is a chain of single prayers, each addressing a different message to a different meta-empirical being or collectively of them. A serial prayer must be taken as many separate prayers as it addresses distinct meta-empirical beings for the purpose of discovering the structure underlying these prayers. Introductory prayers are the, often long, prayers at the beginning of a rite, or a phase or a major ritual episode in a rite. Their function is to initiate con- 
tact between the believers and the being or beings to be addressed by them, to explain to them why the believers have come to them and to state the requests of the believers. Supplementary prayers are the, often short, prayers spoken in the course of a rite, or of a phase or major ritual episode which has opened with an introductory prayer. Supplementary prayers often have a truncated structure. They may lack one or more of the usual structural elements of a prayer, or comprise no more than the barest essentials of the structure of a prayer.

A complete prayer is one of which the full text is available. An incomplete or partial prayer has only some fragments available.

Prayers can have a "one-phase", "two-phase" or "three-phase" structure. A prayer which has a "three-phase" structure, for example, consists of an opening phase, a supplicatory phase and a closing phase. Three structural elements may be found in the opening phase of a prayer: invocation, explanation and offering. In the supplicatory phase, two structural elements may be found: requests and explanations. The concluding phase of a prayer, if present, consists of only one of the following three structural elements: the offering of the gift or the rite; the repetition of the offering of the gift or the rite; or a peroration (Platvoet 1982: 202-207). Rattray as well as Platvoet note that the two-phase structure, comprising an opening and a supplicatory phase, seems to be typical of Akan prayers (Platvoet 1982: 204).

Introductory prayers seem to be the longest and structurally most complete ones. Introductory prayers had the "liminal function of marking the transition from the commerce among the believers to that between the believers and their meta-empirical beings and 'created' the religious atmosphere and ritual context for further communication with them by other modes of address which more fully and more graphically expressed the message which had been stated in the preliminary way in the introductory prayer" (Platvoet 1982: 204). One complete prayer goes like this:

Invocation (opening phase)

Kwabena of the Asante nation,

here is wine,

by your kindness it is Monday today,

Ofiri is your wife,

and Pensan has married her,

and because he did not bring you your

marriage gift,

you lifted them both up

and dashed them to the earth, 
Today Pensan has brought you a sheep, wine and a cloth.

Requests (supplicatory phase)

Long life to both of them, to me Agyeman, long life, do not let me become deaf, do not let me become blind, do not let me become impotent, long life to the 'Castle', to the white man, long life.

Permit Pensan and his wife to have children. To all of us who are here.

(concluding phase)

Ye (all), come, receive this sheep and eat, and this wine and drink (Platvoet 1982: 210).

\section{Libation Pouring Generates Religious Experience}

Libation pouring is particularly important in generating, cultivating and facilitating a religious experience. Different elements which make religious experience possible for the individual and also for the group can be found in libation. Libation contains the experience of participating in something different or sacred which disjoins the constraints of this world commonly known as the Holiness dimension. The experience possesses the confrontation with the "Thou", the unfathomable existence- which is Mystical or the Dialogue with God and gods dimension. Libation experience also involves being the object of the "Thou" or "the Other" and this contains the Intervention dimension which indicates an experience of being "struck" from without. ${ }^{4}$

\footnotetext{
${ }^{4}$ See Wikström, 1993: 89. What Wikström discusses here is a reflection of what Otto developed in 1923. For the latter, it is the encounter with the "holy" that is unique in religion. Elsewhere Hood (1975) has developed what he calls a "mystical experience scale" which can be used to measure intense mystical experience states. They include a set of items such as: (1) a felt loss of identity; (2) a sense of being absorbed into a greater whole; (3) perception of an inner subjectivity of life; (4) a sense of timelessness and spacelessness; (5) belief in the experience as a source of new and valid knowledge; (6) elements of mystery, awe, and reverence; and (7) great difficulty in representing the experience in words. In libation pouring, some of these elements may be seen, for instance, at funeral ceremonies or festivals such as Adae and Odwira. Libation pouring
} 
Religious experiences obtained in the pouring of libation during any ritual festival like Adae or Odwira can be described as peace, joy, forgiveness, nearness to the spirits of ancestors and the gods of the forefathers (Opoku 1970: 133). In addition, individuals perceive themselves as closely related to the spiritual beings. In the case of the Odwira festival, where purification of the whole state is involved, the people become confident and have hope to enter the new year.

At any context, be it a festival such as Odwira or Adae, a regular meeting of elders at the chief's palace or at a healing setting, there are some external factors which influence the faith of the one who makes it and its audience, that is, the okyeame and the social group or community. Music sung in unison constitutes a psychologically important factor since by taking an active part, the behaviour that many people are sharing in, which is a kind of "social facilitation", is increased. The linguistic expressions - the joint confession of faith and acceptance of what the okyeame is requesting from the ancestors and the gods by the people around - serve as a group plausibility structure (Berger and Luckmann 1966: 129-185). This is a fellowship through which the experiences can be legitimized verbally or symbolically in a social context.

There is a common body language waiting to confirm finally what the individual or okyeame leading this experience will say. The nodding of heads by members of the community is one example which indicates that "all this 'behavioural language' is in turn embedded in the overarching religious interpretive framework 'the relationship with the invisible but nonetheless real Other Being"' (Wikström 1993: 93).

The idea that these spiritual beings are in existence and that they answer prayers becomes alive for an individual only if it is confirmed by other important individuals. "The words, the conception of religious reality and its symbolic language - together with the experiences for which the words are an expression - have can survive value only if they are shared" (Wikström 1993: 91). The work of Sundén (1966) has shown that religious words are the bearers of a meaningful content primarily because the individual is part of a social field where others live in a language game where the words refer to similar experiences (Wikström 1993: 91). In libation pouring, the ritual language and its interaction with the holy space play an important function. Normally, the language spoken by the okyeame em-

can lead some individuals to encounter the gods and be possessed, thus fulfilling items 1, 2, and 4. The experiences that ensue after engaging in libation can be said to be mystical and need to be explored in the future (see Spilka, Shaver and Kirkpatrick 1985:1-20). 
phasizes the cognitive content of Akan. The "dual" character of the religious language is therefore of tremendous importance and interest in libation experience.

The interaction between the auditory, visual, verbal and spatial dimension of the place where the ritual of libation pouring takes place is important. The auditory element in the traditional drums and songs which precede the libation experience emphasizes the mythological content. The sound inspires associations with earlier childhood experiences and previous ritual celebrations. For instance, libation poured at Odwira or Adae brings to consciousness familiar close relatives who have recently passed on to the other world (asamando) to become ancestors. It offers a moment of introversion and private meditation which in turn affects primary processes.

The visual as represented by the courtyard (Ahemfie), the shrine or the stool-house (nkonguafieso) of the ancestors emphasizes the sacred. These are the different symbols in stylized form: pots containing water, black stools, knives, calabashes, drums, horns, camel-hair blankets etc. These point to the holy nature of the ritual itself. The shrine of the healer or the stool-house of the chief constitutes a space which is at the same time social and focused. There is an obvious focus of the eye on these sacred things by the okyeame and also the group/elders present. The garment worn by the okyeame and his staff of office emphasizes his role as a holder of office, that he is not present as a private person but a mediator who initiates the dialogue between subjects and the supernatural "Thou". It is made quite clear that he plays a role that is typified, he represents the people to the ancestors and the gods; and ancestors and god to the people.

The okyeame is also a master of the art of gesture. Gestures by the okyeame and the nodding or movement of heads by the group or community members to signify acceptance of what is being said by the okyeame constitute a kind of body language. They point to the basic content of the myths and are all bodily expression of the cognitive content (cf. DeMarinis 1990: 193-210). Libation pouring itself is consequently a form of dramatized yet stylized expression of the religious content it tells about. It offers typified, established and theologically legitimized codes of behaviour (cf. Wikström 1993:94).

\section{Socialization Theory and Libation}

The role of the okyeame is assimilated through the process of socialization. Through learning processes individuals become versed in the mythological 
content, which according to Berger and Luckmann, is a "conception of reality that posits the ongoing penetration of the world of everyday experience by sacred forces" (Berger and Luckmann 1966: 110).

Three categories of people can be listed:

(1) Those who constantly live in the courtyard of the chief (Ahemfie) and witness frequently the okyeame's use of water, wine or beverages to invoke the ancestors and the gods and request their help or assistance. These individuals normally come from the royal family or they have been attached to the courtyard due to their work.

(2) Those who live in a healer's compound and participate constantly in the gathering of the healer. These persons may be closely related to the healer, that is, relatives and friends of the healer. They can also be chief adherents of the cult.

(3) Those who have been born and bred by parents who are traditionalists (adherents of Akan traditional religion) and have special interest in annual participation in the great festivals such as Odwira and Adae. These individuals can fall into any of the above categories.

These individuals meaningfully employ libation ritual when they encounter problems of an existential character.

\section{The Psychological Function of Libation Pouring}

What does libation activity give to the social group and the individuals who privately engage in it? What are the psychological consequences of libation pouring?

\section{The social community}

Libation pouring in general involves the social group or community and the individual chosen as the okyeame to lead the ritual. In a sense, the okyeame acts as a mediator who presents the social group in their interaction with the Supreme Being, deities and ancestors. Though he utters the prayers alone, the community show their involvement and acceptance of what he says by nodding their heads and responding in words. In short, that which is beneficial to the okyeame is beneficial to the social group. Concerning the community, the social solidarity thesis is relevant. This thesis suggests that "ritual exercises control through its promotion of consensus and the psychological and cognitive ramifications of such consensus" (Bell 1992: 171). Many authors, such as Robertson Smith, Evans-Pritchard, Fortes, and Munn have already appealed to this basic feature of ritual, in depicting 
its role in socialization (Bell 1992: 171). Consequently, libation ritual which is an indispensable element in Akan occasional ceremonies, enhances social harmony, which is a prerequisite of every society. In the Adae and Odwira festivals, when all the community come together and libations are poured to invoke the ancestors and the gods, it integrates the social group and the individual both externally and internally.

Another function of ritual applicable to libation ritual has been put forward by M. Gluckman and V. Turner. They suggest that ritual deals with conflicts. Their work, which submits that "ritual controls by forestalling overt rebellion or other threats to social unity, has given rise to the 'channeling of conflict theory.'” According to Gluckman, ritual is like a "safety valve that formally arranges the diffusion of social tensions and personal emotions generated by social conflicts" (Bell 1992: 172). "Tribal rituals," Gluckman notes, "entail dramatization of the moral relations of the group" (Bell 1992: 172). Ritual is "effective because it exhibits all the tensions and strife inherent in social life itself" (Bell 1992: 172). ${ }^{5}$ Elsewhere, Edelman has extended the above approach by saying that ritual can be seen as "preserving strained social relations by simultaneously escalating and orchestrating conflict in such a way that it has to be and can be solved" (Bell 1992: 172). Libation ritual is basically dramatized in order to request peace and the avoidance of conflict not only within the community but also within families. It is the wish of every Akan that the Supreme Being, the ancestors and the gods should prevent anything that will bring discord into homes and the social group at large. When the okyeame who acts as the mediator stands up to utter words of prayer in libation pouring, he does not only remind of the social tensions and strife inherent in the group but he also entreats the ancestors and the gods to help them solve these problems. Often when there is a case in the courtyard (Ahemfie) which needs to be settled, libation plays a major role which helps the elders to settle the case through the direction of the ancestors. Indeed, libation pouring is not only a "tool of cultural management" but a "strategy for maintaining social control" (Bell 1992: 172).

\section{The individual in his private role-taking}

When we come to the personal level, there are also psychological effects of libation pouring for those who know and take the role of the okyeame

\footnotetext{
${ }^{5}$ The work T. Driver (1991) mentions the three great gifts of religious ritual: the establishment of order, the deepening of communal life and the assistance of dynamic of social change through ritual processes of transformation.
} 
model in the myth. As asserted already, such individuals normally find themselves confronted with existential crisis such as illness, being accused of stealing by another who has consulted a god to kill an individual etc. Once motivated by a "need situation", individuals through the backing of beliefs which consequently yield them "expectation" are able to take and adopt roles which result in partnerships with mythical gods or ancestors (Sundén 1970: 22). Dramatic experience of this kind, which leads to libation pouring offers individuals meaning, security in the face of death or illness, and control/power to continue living. The comprehensive meaning to existential questions which accrue to the individual sometimes takes an attributional form. When success as of a request is granted, at times the attribution of success is made to the Other's intentions which often leads to "totality"; "all that happened to him is experienced or seen as a sign about the activity of "the Other" (Unger 1976:16).

An individual who has personally participated in Adae or Odwira become strengthened, in that the prayer/libation provides him with an experience of the real Other (i.e., ancestor or a personal god) who invisibly accompanies him throughout his/her life. This provides him/her with strength and security. There is the notion of being furnished with moral guidance and rehabilitation and forgiveness of past wrongs. Finally, there is a strong feeling of wonder, awe, gratitude, joy and a feeling of being closely related to the Other. The libation experience boosts the self-esteem or selfperception of being protected by the Other and this psychologically blocks up any potential source of anxiety that one will be harmed by an enemy. The fear of being harmed by evil forces is eliminated completely.

\section{Concluding Remarks}

This experience of libation pouring enables Akans to keep and maintain contact with the invisible world of the Supreme Being (God), gods and ancestors. Through the medium of libation, these spiritual beings are fed, purified and worshipped in the Odwira and Adae ceremonies. The experience of libation brings the Akan into the "real" world of the ancestors. The entrance in to their world allows people to communicate with them by requesting for help and also informing them of what is happening in the visible world regarding the tensions and strifes existing in the community. In turn, promises are given to them or suggestions as to the way of solving a problem are given to them by these spiritual beings through the medium of possession of individuals by the spirits or through dreams and divina- 
tion. Libation pouring therefore has some meaningful psychological significance for the social community of the Akan and also for the individual who employs it.

The case of libation pouring can be applicable to any private person who has assimilated the Akan myth. In Sundén's theory term, the background of an individual which has enabled him/her to imbibe the mythological material is able to capacitate him/her to take the role of the okyeame when confronted with existential problems. Like the okyeame in the Akan myth, he/she will take water, alcohol or any beverage, such as, wine to call upon a god or ancestor he/she is familiar with. The interaction that ensues between him/her and the spiritual being becomes the basis upon which attribution of the god's action or success will be made (any external action, happening or an answer to a request, e.g. money). "Intention" which is a concept in Sundén's theory commonly functions in the devotional role of libation pouring. Sometimes a situation can be full of intention in that the individual, without taking okyeame role in the tradition, nevertheless directly identifies a god's action or intervention with the aid of the spiritual role.

Nowadays most people do not regard the beliefs of their forebears as significant, because of the introduction of modern mission schools and the subsequent influence of Christian teachings. But for the traditional Akan these beliefs and the rituals of meaning-making are important. The rituals carry exceptional power and reconcile them with the events of the past and design for them meaning for the future. To these traditional people, "the old gods", forces or gods are not dead, they are part and parcel of their lives.

\section{References}

Akrofi, J. H.

1955 Funeral Dirges of the Akan People. Achimota.

Ayim-Aboagye, Desmond

1993 The Function of Myth in Akan Healing Experience. A Psychological Inquiry into Two Traditional Akan Healing Communities. Uppsala: Uppsala University. (Psychologia et Sociologia Religion um, 9)

Bell, Catherine

1992 Ritual Theory, Ritual Practice. New York: Oxford University Press.

Berger, Peter, and Thomas Luckmann

1966 The Social Construction of Reality. Garden City: Doubleday. 


\section{Busia, Kofi Abrifa}

1954 The Ashanti. In: Daryll Forde (ed.), African Worlds. Studies in the Cosmological Ideas and Social Values of African Peoples; pp. 190-209. Oxford: Oxford University Press.

DeMarinis, Valerie

1990 Movement as Mediator of Memory and Meaning. An Investigation of the Psychological and Spiritual Function of Dance in Religious Ritual, In: Doug Adams and Diane Apostolos-Cappadona (ed.), Dance as Religious Studies. New York: Crossroad.

Driver, Tom F.

1991 The Magic of Ritual. Our Need for Liberating Rites that Transform Our Lives and Our Communities. San Francisco: HarperSanFrancisco.

Durkheim, Emile

1976 The Elementary Forms of the Religious Life. Ed., London: Allen \& Unwin. [2nd ed.]

Hood,

1975 The Construction and Preliminary Validation of a Measure of Reported Mystical Experience. Journal for the Scientific Study of Religion 14:29-41.

Kyerematen, A. A. Y.

s. a. Kingship and Ceremony in Ashanti. Dedicated to the Memory of Otumfuo Sir Osei Agyeman Prempeh II, Asantehene. Kumasi: UST Press.

Opoku, A. A.

1970 Festivals of Ghana. Accra: Ghana Pub. Corp.

Owusu-Mensa, Kofi

1990 Onyamee Kwaame. The Akan God of Saturday. Accra: The Advent Press.

Platvoet, J. G.

1982 Comparing Religions, A Limitative Approach. An Analysis of Akan, Para-Creole, and IFO-Sananda Rites and Prayers. The Hague: Mouton Publishers. (Religion and Reason, 24)

Rattray, R. S.

1923 Ashanti. London: Oxford University Press.

Sarpong, Peter

1974 Ghana in Retrospect: Some Aspects of Ghanaian Culture. Accra: Ghana Publishing.

Sawyerr, Harry

1970 God, Ancestor or Creator? Aspects of Traditional Belief in Ghana, Nigeria \& Sierra Leone. Harlow: Longmans.

Spilka, Bernard, Phillip Shaver, and Lee A. Kirkpatrick

1985 A General Attribution Theory for the Psychology of Religion. Journal for the Scientific Study of Religion 24: 1-20.

Sundén, Hjalmar

1966 Religionen och rollerna. Ett psykologiskt studium av fromheten. Stockholm: Svenska kyrkans diakonistyrelse. [1959]

1970 Kompendium i religionspsykologi. Stockholm: Proprius. 


\section{Unger, Johan}

1976 On Religious Experience. A Psychological Study. Uppsala: Uppsala Universitet. (Acta Universitas Upsaliensis. Psychologia Religionum, 6)

Wikström, Owe

1990 Ritual Studies in the History of Religions. A Challenge for the Psychology of Religion. In: Hans-Günter Heimbrock and H. Barbara Boudewijnse (eds.), Current Studies on Rituals. Perspectives for the Psychology of Religion; pp. 57-71. Amsterdam: Rodopi. (International Series in the Psychology of Religion, 2)

1993 Liturgy as Experience - the Psychology of Worship. A Theoretical and Empirical Lacuna. In: Tore Ahlbäck (ed.), The Problem of Ritual; pp. 83-100. Åbo: The Donner Institute. (Scripta Instituti Donneriani Aboensis, 15) 